\title{
Erratum to: A cross-sectional study on bovine tuberculosis in Hawassa town and its surroundings, Southern Ethiopia
}

\author{
Alemayehu Regassa $\cdot$ Asmelash Tassew $\cdot$ \\ Kebede Amenu • Bekele Megersa • Fufa Abunna • \\ Berhanu Mekibib · Tanguy Marcotty · Gobena Ameni
}

Published online: 26 January 2010

(C) Springer Science+Business Media B.V. 2010

Erratum to: Trop Anim Health Prod

DOI 10.1007/s11250-009-9507-4

TROP-1203ER

Author's name was wrong spelled in the original publication and should be read as Tanguy Marcotty

The online version of the original article can be found under http://dx. doi.org/10.1007/s11250-009-9507-4.

\footnotetext{
A. Regassa $(\bowtie) \cdot$ A. Tassew $\cdot$ K. Amenu $\cdot$ B. Megersa $\cdot$

F. Abunna $\cdot$ B. Mekibib

Faculty of Veterinary Medicine, Hawassa University,

P.O. Box 05, Hawassa, Ethiopia

e-mail: alemregassa@yahoo.com

G. Ameni

Aklilu Lemma Institute of Pathobiology, Addis Ababa University,

P.O. Box 1176, Addis Ababa, Ethiopia

T. Marcotty

Department of Animal Health, Institute of Tropical Medicine,

Nationalstraat 155 ,

2000 Antwerp, Belgium
} 